\title{
IbM Pendidikan Kesehatan Hipertensi dan Pengukuran Kolesterol
}

\author{
Diah Atmarina Yuliani, Khamidah Achyar, Isnaeni Rofiqoch \\ Email: yuliami_da@yahoo.com \\ Prodi Kebidanan D III, Universitas Muhammadiyah Purwokerto, Indonesia \\ J1. Soepardjo Roestam Km. 7, Sokaraja, Purwokerto \\ Telp. (0281) 6844252, 6844253/Fax (0281) 637239
}

\begin{abstract}
Abstrak
Hipertensi merupakan masalah global yang membutuhkan perhatian karena dapat menyebabkan kematian utama di negara maju maupun berkembang. Menurut survey yang dilakukan oleh World Health Organization (WHO) pada tahun 2000, jumlah penduduk dunia yang menderita hipertensi pria sekitar 26,6\% dan wanita sekitar 26,1\% dan diperkirakan pada tahun 2025 jumlahnya akan meningkat menjadi 29,2\%. Di Indonesia pada Riset Kesehatan Dasar tahun 2013 menunjukkan prevalensi PTM ( Penyakit Tidak Menular) antara lain Penyakit Stroke 12,1 per 1000, Penyakit Jantung Koroner 1,5\%, Gagal Jantung 0,3\%, Diabetes Melitus 6,9\%, Gagal Ginjal 0,2\%, Kanker 1,4 per 1000, Penyakit Paru Kronik Obstruktif 3,7\% dan Cidera 8,2\%. RiskesdasTahun 2013 menunjukkan 69,6\% dari Diabetes Melitus dan 63,2\% dari Hipertensi masih belum terdiagnosis.Tujuan kegiatan adalah Meningkatkan pengetahuan ibu tentang hipertensi dan mengetahui kadar kolesterol total. Kegiatan diawali survey ke kelompok sasaran, koordinasi, pengurusan ijin dengan instansi terkait, serta persiapan bahan dan peralatan. Kegiatan pengabdian meliputi pemberian pendidikan kesehatan tentang hipertensi dan kolesterol dan pengukuran kadar kolesterol total. Follow up kegiatan dilakukan dengan hasil monitoring ibu -ibu mengerti dan memamahami hipertensi dan kolesterol merupakan penyakit tidak menular. Pentingnya pengabdian pada masyarakat ini yaitu meningkatnya pengetahuan ibu - ibu tentang beberapa penyakit tidak menular yaitu hipertensi dan kolesterol.
\end{abstract}

Kata Kunci: pendidikan kesehatan; hipertensi; pengukuran kolesterol.

\begin{abstract}
Hypertension is a global problem that requires attention because it can caused major deaths in both developed and developing countries. According to a survey conducted by the World Health Organization (WHO) in 2000, total world population suffering from male hypertension was around $26.6 \%$ and women around $26.1 \%$ it was estimated that by 2025 the number would increase to 29.2\%. Indonesia 2013 Basic Health Research showed the prevalence of PTM (non-communicable diseases) including Stroke 12.1 per 1000, Coronary Heart Disease 1.5\%, Heart Failure 0.3\%, Diabetes Mellitus 6.9\%, Kidney Failure 0.2\%, Cancer 1.4 per 1000, Obstructive Chronic Lung Disease $3.7 \%$ and Injury $8.2 \%$. Riskesdas 2013 showed $69.6 \%$ of Diabetes Mellitus and $63.2 \%$ Hypertension were still undiagnosed. Aim of activity was to increase maternal knowledge about hypertension and know total cholesterol levels. Activity begins with a survey of the target group, coordination, licensing with related agencies, and preparation of materials and equipment. Community service activities include providing health education about hypertension and cholesterol and measuring total cholesterol levels. Follow up activities carried out results of monitoring mothers understand and understand hypertension and cholesterol are noncommunicable diseases. Importance of community service is increased knowledge of mothers about some non-communicable diseases, namely hypertension and cholesterol.
\end{abstract}

Keywords: health education; hypertension; cholesterol measurement. 


\section{Pendahuluan}

Hipertensi merupakan salah satu penyakit tidak menular yang menjadi masalah kesehatan yang serius. Hipertensi pada umumnya terjadi tanpa gejala, sebagian besar orang tidak merasakan apapun, walaupun tekanan darahnya sudah jauh diatas normal, maka hipertensi juga disebut sebagai pembunuh diam-diam atau the silent killer. Keadaan seperti ini dapat berlangsung bertahun-tahun sampai akhirnya penderita jatuh kedalam kondisi darurat dan bahkan bisa terkena stroke atau mengalami gagal ginjal. Komplikasi yang kemudian berujung pada kematian (Hartono, 2011).

Hipertensi lansia sebagian besar merupakan Hipertensi Sistolik Terisolasi (HTS), meningkatnya tekanan sistolik menyebabkan timbulnya stroke dan infark myocard walaupun tekanan diastoliknya dalam batas normal (isolated systolic hypertension). isolated systolic hypertension adalah bentuk hipertensi yang paling sering terjadi pada lansia. Pada lansia banyak faktor-faktor penyebab lainnya dikarenakan faktor usia, dimana semua fungsi dari system tubuh sudah mengalami penurunan fungsi, seperti system kardiovaskuler, musculoskeletal, neurologi, pernafasan dan sebagainya.

Hipertensi merupakan masalah global yang membutuhkan perhatian karena dapat menyebabkan kematian utama di Negara - negara maju maupun berkembang. Menurut survey yang dilakukan oleh World Health Organization (WHO) pada tahun 2000 , jumlah penduduk dunia yang menderita hipertensi untuk pria sekitar $26,6 \%$ dan wanita sekitar $26,1 \%$ dan diperkirakan pada tahun
2025 jumlahnya akan meningkat menjadi 29,2\% (Apriany, 2012).

Di Indonesia pada Riset Kesehatan Dasar tahun 2013 menunjukkan prevalensi PTM (Penyakit Tidak Menular) antara lain Penyakit Stroke 12,1 per 1000, Penyakit Jantung Koroner 1,5\%, Gagal Jantung 0,3\%, Diabetes Melitus 6,9\%, Gagal Ginjal 0,2\%, Kanker 1,4 per 1000, Penyakit Paru Kronik Obstruktif 3,7\% dan Cidera 8,2\%. Riskesdas pada Tahun 2013 menunjukkan bahwa $69,6 \%$ dari Diabetes Melitus dan 63,2\% dari Hipertensi maasih belum terdiagnosis (Kemenkes, 2014).

Data Dinas Kesehatan

Kabupaten Banyumas yang menderita hipertensi pada tahun 2014 sebesar 6.398 orang. Tahun 2015 dari sepuluh besar kasus penyakit, hipertensi menempati urutan pertama dari sepuluh besar penyakit tidak menular yaitu sebanyak 6.748 kasus dan Puskesmas Patikraja menempati urutan 16 dari 27 Puskesmas Kabupaten Banyumas (Dinas Kesehatan, 2016).

\section{Metode}

Kegiatan IbM ini Secara keseluruhan dilaksanakan dengan metode pendekatan sebagai berikut:

a. Pemberian pendidikan kesehatan tentang Hipertensi dan Kolesterol.

b. Melakukan pengukuran kolesterol dalam darah

Kegiatan - kegiatan yang dilaksanakan pada tahap perencanaan adalah sebagai berikut:

a. Melakukan pendekatan pada instansi terkait dan stake holder. Pendekatan dilakukan dengan cara mengirim surat permohonan ijin pengabdian kepada Ketua Ranting Aisyiyah Pamijen Sokaraja 
b. Melakukan

identifikasi

permasalahan dengan cara melakukan pendataan ibu anggota Aisyiyah Ranting Pamijen. Data inilah yang menjadi dasar dalam penentuan rencana tindakan berikutnya.

c. Penyusunan program Pendidikan kesehatan hipertensi dan pengukuran kolesterol, meliputi penyampaian materi, pengukuran, dan melakukan evaluasi.

d. Pemberian pendidikan kesehatan tentang penyakit tidak menular yaitu hipertensi dan kolesterol, serta mengukur kadar kolesterol.

Prosedur Kerja dalam melaksanakan kegiatan IbM dari bulan Oktober 2019 sampai dengan Januari 2020, pelaksana membagi menjadi beberapa tahapan atau prosedur kerja, yaitu:

a. Pemberian informasi atau Pendidikan Kesehatan pada ibu ibu anggota Aisyiyah Ranting Pamijen Sokaraja tentang Hipertensi dan Kolesterol sebagai bagian dari Penyakit Tidak Menular (PTM).

b. Pengukuran kadar kolesterol pada ibu - ibu anggota Aisyiyah Ranting Pamijen Sokaraja.

c. Evalusi untuk mengukur keberhasilan program yang dilakukan.

\section{Hasil dan Pembahasan}

Para peserta yang terdiri dari perempuan dan ibu yang tergolong dalam usia muda dan lansia dengan usia antara 35 hingga 64 tahun. Latar belakang pendidikan yang dimiliki oleh perempuan dan ibu tersebut adalah bervariasi, ada yang tamat sekolah menengah pertama dan juga tamat sekolah atas dan ada yang tamat sarjana. Tetapi dari ketiga tamatan tersebut, yang terbanyak adalah tamatan sekolah menengah atas. Pada awal pelatihan hasil pemberian pre test dan Ranting Aisyiyah Pamijen Sokaraja yang dilakukan, secara umum mengindentifikasikan pengetahuan tentang hipertensi dan kolesterol termasuk dalam PTM (Penyakit Tidak Menular) secara umum masih belum baik.

Diagram Hasil Pre test dan Post tes hipertensi dan kolesterol.

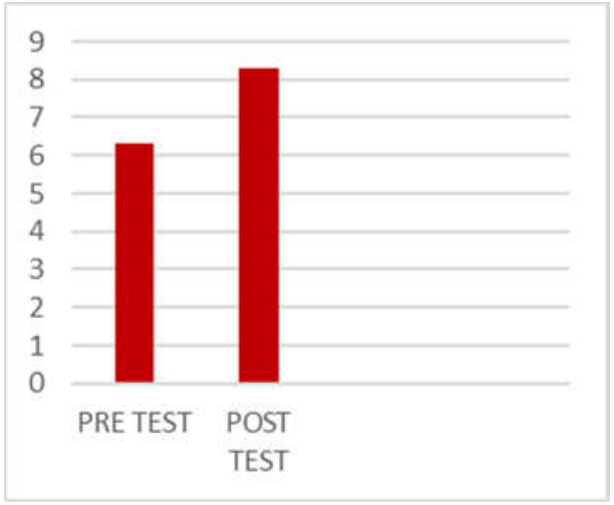

Hal ini sesuai dengan pendapat Notoatmodjo (1993) dalam Hasanah (2012) yang menyebutkan bahwa tingkat pendidikan juga menentukan mudah tidaknya seseorang memahami pengetahuan yang mereka peroleh, pada umumnya semakin tinggi pendidikan seseorang semakin baik pengetahuannya.

Pemberian Pendidikan kesehatan hipertensi, kolesterol dan pengukuran kolesterol Ranting Aisyiyah Pamijen Sokaraja berlangsung lancar, perempuan muda dan ibu-ibu mempunyai antusiasme sangat baik.

Kondisi perempuan muda dan ibu-ibu pada saat pelaksanaan sangat antusias dan partisipasinya baik. Hal ini terlihat dari banyaknya pertanyaan tentang hipertensi dan kolesterol dalam darah, ibu yang datang tepat waktu dan mengikuti kegiatan sampai dengan selesai. 


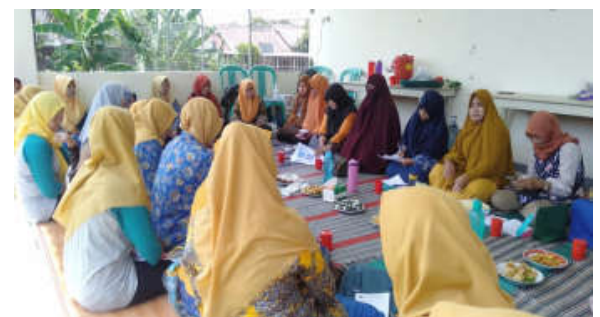

Gambar 1. Pendidikan Kesehatan tentang hipertensi dan kolesterol

Peningkatan pemahaman dan keterampilan ini secara psikologis membuat ibu lebih mengerti dan meningkatkan kesadaran tentang pentingnya menjaga pola makan dan gaya hidup.

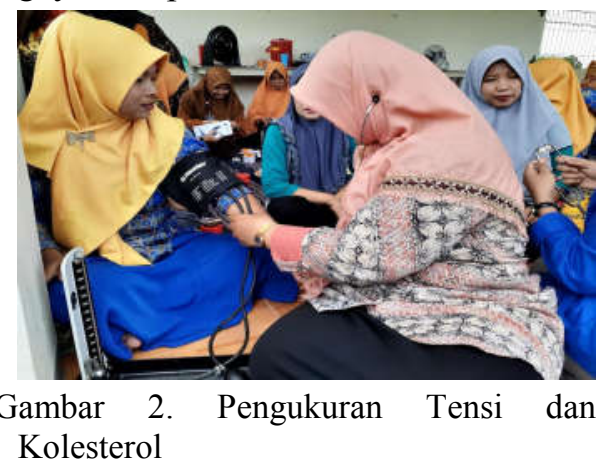

Tabel 1. Hasil pengukuran Tensi dan Kolesterol

\begin{tabular}{llll}
\hline No & Responden & $\begin{array}{c}\text { Hasil } \\
\text { (Tensi) }\end{array}$ & $\begin{array}{c}\text { Hasil } \\
\text { (Kolesterol) }\end{array}$ \\
\hline 1 & R1 & $110 / 80$ & 221 \\
2 & R2 & $100 / 80$ & 218 \\
3 & R3 & $100 / 90$ & 235 \\
4 & R4 & $110 / 70$ & 173 \\
5 & R5 & $120 / 85$ & 228 \\
6 & R6 & $110 / 70$ & 229 \\
7 & R7 & $110 / 80$ & 249 \\
8 & R8 & $110 / 70$ & 249 \\
9 & R9 & $110 / 80$ & 276 \\
10 & R10 & $110 / 70$ & 258 \\
11 & R11 & $120 / 70$ & 235 \\
12 & R12 & $130 / 90$ & 282 \\
13 & R13 & $120 / 80$ & 244 \\
14 & R14 & $125 / 70$ & 227 \\
15 & R15 & $100 / 70$ & 237 \\
16 & R16 & $140 / 70$ & 236 \\
17 & R17 & $130 / 80$ & 259 \\
18 & R18 & $120 / 90$ & 255 \\
\hline
\end{tabular}

Dari hasil pengukuran kadar kolesterol total sebanyak 1 responden berada pada kadar kolesterol total normal, 9 responden pada kadar kolesterol total kategori wasapada/hati - hati, 8 lainnya termasuk pada kadar kolesterol total tinggi.

Nilai kadar kolesterol tersebut berdasarkan tabel Nilai Normal Kolesterol Total dari P2PTPM Kemenkes RI, yaitu Tinggi $>240 \mathrm{mg} / \mathrm{dl}$, Normal/Baik $<200 \mathrm{mg} / \mathrm{dl}$ (P2PTM Kemenkes RI, 2019)

\section{Kesimpulan}

Berdasarkan hasil kegiatan IbM dapat disimpulkan Pemahaman ibu Ranting Aisyiyah Pamijen Sokaraja dapat meningkat melalui pemberian Pendidikan kesehatan dan pemahaman pengetahuan hipertensi dan kolesterol dalam darah.

\section{Daftar Pustaka}

[1] Apriany, REA dan Mulyati, T, Asupan Protein, Lemak Jenuh, Natrium, serat dan IMT terkait dengan Tekanan Darah Pasien Hipertensi Di RSUD Tugurejo Semarang. Journal of Nutrition College, 2004.

[2] Dinas Kesehatan kabupaten Banyumas, Profil Kesehatan Kabupaten Banyumas 2016, Banyumas: Erlangga, 2016

[3] Hartono, Bambang, Hipertensi Pembunuh Diam-diam, Diaskes. [Online]. http://health.kompas.com/read/ 2011/05/16/02522321/hiperten si.pembunuh.diam-diam, 2011.

[4] Hasanah, Aan, Pengembangan Profesi Guru, Bandung: CV. Pustaka Setia, 2012. 
[5] Kementrian Kesehatan Indonesia, Riskesdas Tahun 2013, Jakarta: Kementrian Badan dan Pengembangan Kesehatan Republik Indonesia, 2014.

[6] P2PTM Kementrian Kesehatan Republik Indonesia, Nilai Kolesterol Normal,. [Online]. http://p2ptm.kemkes.go.id/info graphic-p2ptm/hipertensipenyakit-jantung-danpembuluh-darah/berapa-nilainormal-kolesterol-total, 2019. 